\title{
CONTROLE DE CRESTAMENTO BACTERIANO COMUM (XANTHOMONAS AXONOPODIS PV. PHASEOLI) E ALTERAÇÕES BIOQUÍMICAS EM FEIJOEIRO INDUZIDAS POR PYCNOPORUS SANGUINEUS
}

\author{
S.L. Toillier ${ }^{1}$, L. Iurkiv ${ }^{1}$, C.C. Meinerz ${ }^{1}$, M. Baldo ${ }^{1}$, C.A. Viecelli ${ }^{1}$, \\ O.J. Kuhn ${ }^{2}$, K.R.F.Schwan-Estrada ${ }^{3}$,J.R.Stangarlin ${ }^{1}$
}

${ }^{1}$ Universidade Estadual do Oeste do Paraná, Centro de Ciências Agrárias, CP 91, CEP 85960-000, Marechal Cândido Rondon, PR, Brasil. E-mail: jrstangarlin@unioeste.br

\section{RESUMO}

\begin{abstract}
O objetivo deste trabalho foi verificar as atividades antibacteriana e indutora de resistência de extratos de Pycnoporus sanguineus para controle do crestamento bacteriano comum, causado por Xanthomonas axonopodis pv. phaseoli, em feijoeiro. In vitro foram utilizados extratos aquosos de basidiocarpo, micélio e filtrado de cultura de $P$. sanguineus nas concentrações de 1, 5, 10, 15 e 20\%, além das testemunhas água, acibenzolar-S-metil (ASM - $125 \mathrm{mg}$ i.a. L $\mathrm{L}^{-1}$ ) e antibiótico $\left(22,5 \mathrm{mg} \mathrm{L}^{-1}\right.$ de oxitetraciclina $+225 \mathrm{mg} \mathrm{L}^{-1}$ de estreptomicina). In vivo foram realizadas avaliações de severidade e atividade de peroxidase, polifenoloxidase, $\beta-1,3$ glucanase e fenilalanina amônia-liase, com o uso de extrato aquoso de micélio e de basidiocarpo e filtrado de cultura de $P$. sanguineus a $5 \%$ e $10 \%$. Verificou-se atividade antibacteriana apenas para o filtrado de cultura em concentrações acima de $15 \%$ e para o extrato de basidiocarpo nas concentrações de 1 a $20 \%$. In vivo, os resultados indicaram o potencial de extratos de basidiocarpos de $P$. sanguineus para o controle de $X$. axonopodis pv. phaseoli em feijoeiro, com redução média de $56 \%$ na severidade, o que pode ter ocorrido tanto por atividade antimicrobiana direta quanto por indução de resistência, envolvendo principalmente a ativação das enzimas de defesa vegetal peroxidase e polifenoloxidase.
\end{abstract}

PALAVRAS-CHAVE: Controle alternativo, indução de resistência, proteínas relacionadas à patogênese, atividade antimicrobiana.

\begin{abstract}
CONTROLOF BACTERIAL BLIGHT (XANTHOMONAS AXONOPODIS PV. PHASEOLI) AND BIOCHEMICAL ANALYSES OF BEAN RESISTANCE TREATED WITH PYCNOPORUS SANGUINEUS EXTRACTS. The aim of this work was to verify the antimicrobial and resistance induction activities of Pycnoporus sanguineus extracts for the control of common bacterial blight caused by Xanthomonas axonopodis pv. phaseoli. In vitro assays were performed using aqueous extracts from basidiocarp, mycelium and culture filtrate of $P$. sanguineus in concentrations of 1 , 5, 10, 15 and 20\%, with water, acibenzolar-S-methyl (ASM - $125 \mathrm{mg}$ a.i. $\mathrm{L}^{-1}$ ) and antibiotic (oxytetracycline $22.5 \mathrm{mg} \mathrm{L}^{-1}+$ streptomycin $225 \mathrm{mg} \mathrm{L}^{-1}$ ) as control treatments. For the in vivo assays the disease severity and the activities of peroxidase, polyphenol oxidase, $\beta-1,3$ glucanase and phenylalanine ammonia-lyase were evaluated using extracts of mycelium, basidiocarp and culture filtrate of $P$. sanguineus at $5 \%$ and $10 \%$. Antibacterial activity was verified only for culture filtrate in concentrations above $15 \%$ and for concentrations of $1 \%$ to $20 \%$ of basidiocarp extract. The results of the in vivo assays indicated the potential of basidiocarps extracts from $P$. sanguineus for the control of $X$. axonopodis pv. phaseoli in beans, with an average severity reduction of $56 \%$, which may have been due either to direct antimicrobial activity or to resistance induction involving mainly the activation of the plant defense enzymes peroxidase and polyphenol oxidase.
\end{abstract}

KEYWORDS: Alternative control, resistance induction, pathogenesis related proteins, antimicrobial activity.

${ }^{2}$ Universidade Federal do Pampa, Itaqui, RS, Brasil.

${ }^{3}$ Universidade Estadual de Maringá, Departamento de Agronomia, Maringá, PR, Brasil. 


\section{INTRODUÇÃO}

O feijoeiro (Phaseolus vulgaris L.) pode ser afetado por mais de 300 doenças causadas por vírus, bactérias, fungos e nematoides, as quais contribuem para o seu baixo rendimento, em todas as regiões do mundo onde é cultivado (BIANCHINI et al., 2005). Os danos são observados desde a semeadura até quando os grãos estão secos nas vagens. Muitas dessas doenças podem causar, deacordo com as condições do ambiente, danos totaisna produção ou, dependendodonível de contaminação, tornar inviáveis determinadas áreas para o cultivo.

Dentre as doenças de origem bacteriana que afetam a cultura do feijoeiro, o crestamento comum causado por Xanthomonas axonopodis pv. phaseoli é a que apresenta maior importância (SARTORATO et al., 1996), devido à capacidade de reduzir a produção de forma significativa e às dificuldades de controle (VAle et al., 1997). Dessa forma, é necessário desenvolver novos métodos de controle para tal doença, como a indução de resistência em plantas usando produtos naturais (SCHWAN-ESTRADA;STANGARLIN, 2005).

A indução de resistência envolve a ativação de mecanismos de defesa latentes existentes nas plantas em resposta ao tratamento com agentes eliciadores os quais são moléculas capazes de ativar mecanismos de defesa na planta, protegendo-a contra infecções subsequentes por patógenos (STANGARLIN et al., 1999). Entre os eliciadores não convencionais podem-se incluir os extratos de plantas medicinais e óleos essenciais (STANGARLIN etal.,2008), bem como os extratos obtidos de cogumelos (Di PIERO et al., 2005).

Entre os basidiomicetos com propriedades eliciadores destaca-se Pycnoporus sanguineus (L. ex Fr.) Murr., utilizado desdea medicina popular (SMÂNIA et al., 1995) até ao controle alternativo de doenças de plantas (Peiter-Beninca et al., 2008; IURKIV, 2009), com potencial para a indução de resistência, tornando-se promissor em pesquisas relacionadas.

Em vista do exposto, este trabalho teve como objetivos investigar o uso de extratos aquosos de basidiocarpo, micélio ou filtrado de cultura de $P$. sanguineus para controle do crestamento bacteriano comum do feijoeiro, por meio de avaliações da atividade antimicrobiana in vitro contra X. axonopodis pv. phaseoli e da indução de resistência pela ativação das enzimas de defesa vegetal peroxidase, polifenoloxidase, fenilalanina amônia-liase e $\beta-1,3-$ glucanase.

\section{MATERIALEMÉTODOS}

O trabalho foi realizado no Laboratório de Fitopatologia da Universidade Estadual do Paraná-
UNIOESTE-Campus de Marechal CândidoRondon, PR. Para os ensaios deindução de resistência, plantas de feijoeiro cultivar Carioca IAPAR 81 foram cultivadas em vasos plásticos (com capacidade para 1,5 L) contendo mistura de solo, areia e matéria orgânica (proporção 2:1:1) e mantidas em cultivo protegido (Assi, 2005). Foram utilizadas duas plantas por vaso. A bactéria $X$. axonopodis pv phaseoli foi isolada de folhas sintomáticas provenientes de cultivos comerciais de feijoeiro do Município de Marechal Cândido Rondon, PR.

\section{Obtenção do filtrado de cultura e dos extratos aquosos de $P$. sanguineus}

Basidiocarpos de $P$. sanguineus foram coletados nas matas da região Oeste do Paraná e, posteriormente, secos em temperatura constante de $30^{\circ} \mathrm{C}$ para serem moídos em moinho de facas. O preparo de extratos aquosos de basidiocarpo constituiu na hidratação do pó seco de basidiocarpos por 24h à temperatura de $4^{\circ} \mathrm{C}$ (mantidos em geladeira), na proporção de $14 \mathrm{~mL}$ deágua destilada para $1 \mathrm{~g}$ de pó seco debasidiocarpo, sendoem seguida filtrados em papel filtro Whatman $n^{\circ} 1$ (Di Piero; Pascholati, 2004). Os filtrados coletados foram esterilizados por filtração em membrana com $0,45 \mu \mathrm{m}$ de diâmetro de poro, em câmara de fluxo laminar. Esses filtrados armazenados em geladeira a $4^{\circ} \mathrm{C}$ foram utilizados após diluições para obter as concentrações de 1, 5, 10, 15 e 20\% para os testes in vitro e nas concentrações de 5 e $10 \%$ para os ensaios de proteção de plantas (Assi, 2005).

Para obtenção do micélio de $P$. sanguineus, foram preparados $100 \mathrm{~mL}$ de meio de cultura BD (batatadextrose), nos quais foram repicados cinco discos contendomeiodecultura mais micéliode P. sanguineus, crescido por 14 dias em meio BDA e em escuro a $25^{\circ} \mathrm{C}$, sob agitação (150 rpm). Após vinte dias, o conteúdo decada frasco foi filtradoem papel filtro Whatman $n^{\circ} 1$. O material que passou pelo filtro foi considerado o filtrado de cultura, sendo utilizado nas concentrações de 1, 5, 10, 15 e $20 \%$ para os testes in vitro e nas concentrações de 5 e $10 \%$ para os ensaios de proteção de plantas. O micélio retido no filtro foi colocado em estufa a $40^{\circ} \mathrm{C}$ até obtenção de peso constante e, posteriormente, macerado em almofariz de porcelana para obtenção do pó. Esse pó de micélio foi hidratado em água destilada na proporção definida anteriormente, constituindo assim o extrato aquoso demicélio e utilizado nos testes in vitro e de proteção de plantas.

\section{Atividade antibacteriana}

Para esse ensaio foi preparado meio de cultura caldo nutriente (extrato de carne: $3 \mathrm{~g}$; peptona: $5 \mathrm{~g}$; glicose: $15 \mathrm{~g}$; água destilada: $1.000 \mathrm{~mL}$ ) (MARIANO; 
SilveIrA, 2000). O meio esterilizado (10 $\left.\mathrm{mL}^{\text {tubo }}{ }^{-1}\right)$ recebeu as diferentes concentrações do filtrado e dos extratos de $P$. sanguineus $(1,5,10,15$ e $20 \%)$, esterilizados por filtração. Uma alíquota de $100 \mu \mathrm{L}$ de suspen-

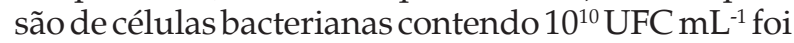
adicionada a cada tubo, os quais foram incubados a $28^{\circ} \mathrm{C}$ por 48 h em estufa incubadora sob agitação a 150 rpm. A avaliação do número de bactérias foi realizada por espectrofotometria, anotando-se a absorbância a $560 \mathrm{~nm}$ de cada amostra e calculando-se o valor de UFCs deacordocoma curva decrescimentobacteriano previamente elaborada. Apenas o meio de cultura foi utilizado como tratamento controle.

\section{Indução de resistência}

Foirealizadooensaiocom X.axonopodis pv.phaseoli com os seguintes tratamentos: (a) testemunha ou controle negativo: plantas tratadas com água destilada; (b) controle positivo $\mathrm{n}^{\circ} 1$ : bactericida sistêmico Agrimicina $\left(22,5 \mathrm{mg} \mathrm{L}^{-1}\right.$ de oxitetraciclina $+225 \mathrm{mg} \mathrm{L}^{-}$ ${ }^{1}$ deestreptomicina); (c) controle positivo ${ }^{\circ} 2$ : indutor de resistência - acibenzolar-S-metil (125 mg i.a. $\left.\mathrm{L}^{-1}\right)$; (d) extrato debasidiocarpos, (e) de micélioe (f) filtrado de cultura de $P$. sanguineus, em concentrações de 5 e $10 \%$.

Os tratamentos, em quantidade de $3 \mathrm{~mL}$, foram aplicados na primeira folha trifoliada três dias antes da inoculação do patógeno. A inoculação foi realizada na primeira folha trifoliada tratada, bem como na segunda folha trifoliada não tratada, para se observar a ocorrência de proteçãolocale/ou sistêmica, respectivamente. As inoculações foram realizadas na parte da manhã, mediante aspersão de suspensão de inóculo contendo $5 \times 10^{7} \mathrm{UFC} \mathrm{mL}^{-1}$ (RAVA; SARTORATO, 1994). Após a inoculação, as plantas foram cobertas com sacos de polipropileno com água destilada aspergida para simular câmara úmida por $24 \mathrm{~h}$ (STANGarLin; Pascholati, 2000). Após esse período, a câmara úmida foi removida e as plantas ficaram em casa de vegetação climatizada a $28^{\circ} \mathrm{C}$. A avaliação da severidade foi realizada 12 dias após os tratamentos, por determinação da área lesionada com o auxílio do sistema computacional QUANT v. 1.0.2 (VALE et al., 2003).

\section{Coleta de amostras para análises bioquímicas}

Foram coletados três quadrados $\left(1 \mathrm{~cm}^{2}\right)$ de folha por amostra no momento dos tratamentos e também nos $3^{\circ}, 6^{\circ}, 9^{\circ} \mathrm{e} 12^{\circ}$ dias após. Durante o procedimento, cada amostra coletada foi imediatamente acondicionada em envelopes de papel alumínio e congelada a $-20^{\circ} \mathrm{C}$. Coletaram-seamostras nas $1{ }^{\text {as }}$ folhas trifoliadas inoculadas, bem como nas $2^{\text {as }}$ folhas trifoliadas nãoinoculadas.

\section{Obtenção dos extratos proteicos}

As amostras de folhas foram homogeneizadas mecanicamente em $2 \mathrm{~mL}$ de tampão fosfato de sódio $0,01 \mathrm{M}(\mathrm{pH} 6,0)$ (tampão de extração), em almofariz de porcelana. O homogenato foi centrifugado a $6.500 \mathrm{~g}$ durante $10 \mathrm{~min}$ a $4^{\circ} \mathrm{C}$, sendo o sobrenadante obtido considerado como extrato enzimático, para posterior determinação da atividade de peroxidase, polifenoloxidase, fenilalanina amônia-liase, $\beta-1,3-$ glucanase e conteúdo proteico.

\section{Atividade de peroxidase}

Aatividadedeperoxidasesfoi determinada $30^{\circ} \mathrm{C}$, através demétodoespectrofotométricodiretoa $470 \mathrm{~nm}$, utilizando guaiacol e peróxido de hidrogênio como substrato (Lusso; Pascholati, 1999). A atividadeespecífica de peroxidase foi expressa em absorbância min ${ }^{1} \mathrm{mg}$ de proteína ${ }^{-1}$.

\section{Atividade de polifenoloxidase}

A atividade de polifenoloxidase foi determinada de acordo com a metodologia de DUANGMAL; APENTEN (1999), mensurando-se a oxidação do catecol convertido em quinona. Os resultados foram expressos em absorbância $\min ^{-1} \mathrm{mg}$ de proteína ${ }^{-1}$.

\section{Determinação da atividade da fenilalanina amô- nia-liase}

A atividade da fenilalanina amônia-liase (FAL) foi determinada a $37^{\circ} \mathrm{C}$ por espectrofotometria direta medida pela conversão de L-fenilalanina em ácido transcinâmico a $290 \mathrm{~nm}$ (STANGARLIN et al., 2005). Os resultados foram expressos em $\mathrm{mg}$ de ácido transcinâmico $\mathrm{h}^{-1} \mathrm{mg}$ de proteína ${ }^{-1}$.

\section{Atividade de $\beta-1,3$ glucanase}

A atividade da $\beta-1,3$ glucanase foi avaliada segundometodologia descrita porStANGARLIN etal. (2005). A reação foi determinada pela quantificação colorimétrica de glicose liberada da laminarina, através do uso da hidrazida do ácido $p$-hidroxibenzóico (HAPHB). As leituras de absorbância foram plotadas em curva padrão para glicose e os resultados expressos em $\mu$ g de glicose min $^{-1} \mathrm{mg}$ de proteína ${ }^{-1}$.

\section{Teor de proteína}

Oteor de proteínas totais foi avaliado pelo método de BRADFORD (1976). A concentração de proteínas, expressa em termos equivalentes de $\mu \mathrm{g}$ de albumina desorobovino(ASB) em $1 \mathrm{~mL}$ de amostra ( $\mu$ g proteína 
$\mathrm{mL}^{-1}$ ), foi determinada utilizando-se curva padrão de concentrações de ASB, variando de 0 a $20 \mu \mathrm{g} \mathrm{mL}^{-1}$.

\section{RESULTADOSEDISCUSSÃO}

\section{Atividade antimicrobiana}

A análise de variância do efeito das concentrações do extrato de $P$. sanguineus sobre o crescimento bacteriano de X. axonopodis pv. phaseoli indicou que o extrato de micélio (Fig. 1A) estimulou o crescimento da bactéria de forma dose-dependente. O filtrado a $20 \%$ reduziu em $21 \%$ o crescimento bacteriano quando comparado àqueleem meio de cultura na ausência dos tratamentos (indicado no gráfico como concentração zero) (Fig. 1B). Os extratos de basidiocarpo em $15 \%$ e $20 \%$ reduziram $91 \%$ em média o crescimento bacteriano, comportando-se estatisticamente igual ao antibiótico, que reduziu ocrescimento em $81 \%$ (Fig. 1C). O acibenzolar-S-metil (ASM) não apresentou atividade antibiótica.

Na literatura não há relatos sobre a ação antimicrobiana de extratos de $P$. sanguineus contra bactérias fitopatogênicas, mas apenas para fungos. Para BALDO (2008), a análise dos dados do ensaio in vitro da germinação de esporos de Colletotrichum lindemuthianum revelou que os extratos aquosos de basidiocarpode $P$. sanguineus tiveram efeito inibitório na germinação em até $97 \%$. Semelhantemente, Assi (2005) observou que extratos aquosos de basidiocarpos de P. sanguineus reduziram em até $96 \%$ a germinação in vitro deesporos deC. lindemuthianum.

VIECELLI et al. (2008) puderam verificar, no ensaio degerminaçãodeesporos dePseudocercosporagriseola, que extratos de micélio de $P$. sanguineus, a partir da concentração $5 \%$, inibiram significativamente a germinação, enquanto extratos de basidiocarpos e de filtrado de cultura de P. sanguineus não apresentaram efeito significativo.

BALDO et al. (2008) observaram que extratos aquosos de basidiocarpos de $P$. sanguineus nas concentrações 5, 10, 15 e $20 \%$ inibiram significativamente a germinação de esporos de Uromyces appendiculatus e de Phakopsora euvitis em até $79 \%$ e $73 \%$, respectivamente, em relação à testemunha água.

\section{Avaliação da severidade}

Tanto para a primeira folha tratada e inoculada (Fig. 2A) quanto para a segunda folha apenas inoculada (Fig. 2B), a severidade foi menor nas plantas que receberam filtrado de cultura de $P$. sanguineus a 5 e $10 \%$. Na $1^{\text {a }}$ folha tratada com o filtrado decultura a $5 \%$, a redução da doença, quando comparado à água, foi de $33,44 \%$ e com o uso do filtrado de cultura a $10 \%$ foi de $21,73 \%$, ao passo que na $2^{\mathrm{a}}$ folha, tanto o tratamento com filtrado a $5 \%$ quanto a $10 \%$, reduziram em quase $90 \%$ a severidade, quando comparados com a testemunha água. Resultados semelhantes foram observados nos tratamentos com extratos de basidiocarpo e de micélio e com antibiótico. Isso indica que os tratamentos à base de $P$. sanguineus podem ter induzidotanto resistência local quanto sistêmica em feijoeiro ao crestamento bacteriano. Na literatura não há relatos do uso de indutores dessa natureza para controle desta doença em feijoeiro.

\section{Atividade de enzimas de defesa vegetal}

\section{Peroxidase}

As plantas de feijão que receberam extratos de basidiocarpo e de micélio e filtrado de cultura na $1^{\text {a }}$ folha, tratada e inoculada, bem como na $2^{a}$ folha, não tratada einoculada, apresentaram oscilação no incremento da atividade de peroxidase quando comparados às testemunhas água, antibiótico e ASM (Fig. 3).

Para o extrato de basidiocarpo a $10 \%$ na $1^{\text {a }}$ folha, observou-se incremento da atividade de peroxidase aos 6 DAT, diminuindo sua expressão no $9^{\circ} \mathrm{DAT}$, voltandonovamenteao mesmo patamar deexpressão observadono $6^{\circ} \mathrm{DAT}$ para o $12^{\circ} \mathrm{DAT}$, quandocomparadoàs testemunhas e aos demais tratamentos, sendo superior ao $\mathrm{ASM}$ em $90 \%$ no $6^{\circ} \mathrm{DAT}$ e à testemunha água em $135 \%$ no $12^{\circ}$ DAT. O micélio a $10 \%$ foi superior em $200 \%$ à testemunha água ao $6^{\circ} \mathrm{DAT}$, e o filtrado de cultura a 5\% apresentou incrementos na atividade da peroxidase de forma mais expressiva no $6^{\circ} \mathrm{DAT}$, sendo $165 \%$ superior à testemunha água.

Nomomento da inoculação do patógeno $\left(3^{\circ} \mathrm{DAT}\right)$, a maior atividade específica da peroxidase na $2^{\mathrm{a}}$ folha foi observada no tratamento com filtrado a 5 e $10 \%$, sendo que o primeiro foi $76 \%$ superior à testemunha água eo segundo $65 \%$.Oextrato debasidiocarpo a $5 \%$ e o filtrado a $10 \%$ apresentaram maior atividade ao $6^{\circ}$ DAT, com o primeiro sendo superior à testemunha água em mais de $300 \%$ e o segundo em $65 \%$.

BALDO et al. (2008) observaram incremento na atividade da peroxidase em função dos tratamentos com extrato de basidiocarpo, micélio e filtrado de cultura de $P$. sanguineus em feijoeiro, na $3^{\text {a }}$ folha tratada, bem como na $4^{\mathrm{a}}$ folha não tratada e inoculada, demonstrando a sistemicidade do efeito em função dos tratamentos, resultado esse também encontrado por VIECELLI (2008).

Para MeInerz et al. (2007), o extrato bruto de basidiocarpo de P. sanguineus, na concentração de $5 \%$, promoveu incremento na atividade de peroxidase de $41 \%$ em cotilédones de soja, ao passo que o ASM promoveu resultadossemelhantesà testemunhaágua. Já IURKIV (2009) pôde observar que a aplicação de extrato aquoso de basidiocarpo de $P$. sanguineus a $20 \%$ 
apresentou característica supressora da atividade de peroxidase em cotilédones de soja, proporcionando redução de $61,6 \%$ na atividade em relação a testemunha água.

PeITER-Beninchet al.(2008), avaliando a indução de peroxidases, verificaram que os extratos diclorometânico, hexânico e etanólico de basidiocarpos de $P$. sanguineus, em mesocótilos de sorgo e cotilédones de soja, inibiram a atividade enzimática. A indução verificada para o extrato hexânico em sorgo não diferiu do controle ASM, e em soja a atividade foi inibida pelo extrato etanólico e induzida pelo hexânico, mas sem diferir do tratamento com ASM.

\section{Polifenoloxidase}

A maior atividade específica de polifenoloxidase na $1^{\text {a }}$ folha foi com o EA de basidiocarpo a $5 \%$ aos 12 DAT, ao passo que na $2^{\mathrm{a}}$ folha, sua maior atividade foi a $10 \%$ no $9^{\circ}$ DAT. Comparando-se os tratamentos em ambas as folhas, o extrato de basidiocarpo a 5\% foi superior ao ASM em 1000\%, e o basidiocarpo a $10 \%$ foi superior em $500 \%$ à testemunha água (Fig. 4). O filtrado a $10 \%$ na $1^{\text {a }}$ folha, aos 9DAT, foi superior à testemunha água em $150 \%$. O micélio a 10\% na $1^{\text {a }}$ folha, quando comparado à testemunha água aos $12 \mathrm{DAT}$, foi superior em $44 \%$. Para o micélio a $5 \%$, no momento da inoculação do patógeno ( $\left.3^{\circ} \mathrm{DAT}\right)$ na $2^{\mathrm{a}}$ folha, a atividade apresentou-se de forma acentuada, sendo superior à água em 240\%, com estabilização da expressão no decorrer dos dias.

Estes resultados são semelhantes aos de VIECELLI (2008), que verificou que a atividade dessa enzima foi influenciada pelos tratamentos com extratos de $P$. sanguineus, na $3^{\mathrm{a}}$ folha tratada, bem como na $4^{\mathrm{a}}$ folha não tratada e inoculada, demonstrando a sistemicidade do efeito indutor.

Dependendo da combinação elicitor - planta hospedeira, a resposta para polifenoloxidase pode ser diferente da encontrada neste trabalho. Em soja, MeINERZ et al. (2007) verificaram decréscimo da atividade dessa enzima em função do aumento da concentração do extrato de basidiocarpo de P. sanguineus. KUHN (2007) observou que a atividade específica de polifenoloxidase em feijoeiro não foi alterada em função dos indutores Bacillus cereus e ASM.

\section{Fenilalanina amônia-liase}

A atividade específica de fenilalanina amônialiase pouco incrementou no decorrer dos dias em função dos tratamentos com basidiocarpo, micélio e filtrado de cultura de $P$. sanguineus, local ( $1^{\text {a }}$ folha, tratada e inoculada) e sistemicamente ( $2^{\text {a }}$ folha, apenas inoculada)(Fig. 5). Na $1^{\text {a }}$ folha, todos os tratamentos, comparados às testemunhas, tiveram comportamento semelhante, verificando aqui quea indução de resistência não foi ativada em função dos tratamentos, mas sim, em função do patógeno desafiador aplicado.Pode-se observar apenas que o extrato demicélio a $10 \%$ proporcionou incremento na atividade da FAL em $460 \%$ quando comparado à testemunha água.

$\mathrm{Na} 2^{\text {a }}$ folha, a maior expressão da enzima ocorreu aos9DATnotratamentocomoextrato debasidiocarpo a 10\%, superior à testemunha água em mais de $1000 \%$. De modo geral, a análise estatística indica que não houve incrementos significativos na atividade específica da FAL com a utilização dos extratos de $P$. sanguineus. O mesmo pôde ser observado por KuHN (2007) em feijoeiros tratados com B. cereus e ASM. Segundo o autor, isto pode significar que toda a rota dos fenilpropanoides não sofreu alterações como, por exemplo, os mecanismos de síntese de lignina, compostos fenólicos e quinonas, entre outros.

\section{$\beta-1,3$ glucanase}

Assim como para FAL, a atividade específica de $\beta$ 1,3 glucanase teve pouco incremento no decorrer dos dias em função dos tratamentos com basidiocarpo, micélio e filtrado de cultura de $P$. sanguineus, local e sistemicamente (Fig. 6). Observou-se que na $2^{\text {a }}$ folha apenas inoculada, a expressão da atividade foi maior aos 9 DAT com o extrato de basidiocarpo a 10\%, superior a água em 1200\%, indicando indução sistêmica, e o filtrado de cultura a 10\% foi superior à testemunha água em 100\%. Resultados semelhantes foram obtidos por VIECELLI (2008), onde a atividade da $\beta-1,3$ glucanase em feijoeiro foi influenciada pelos tratamentos com extratos de $P$. sanguineus, na $3^{\text {a }}$ folha tratada, bem como na $4^{\mathrm{a}}$ folha não tratada e inoculada com P. griseola, comprovando a sistemicidade do efeito também para esse patossistema.

Para outros patossistemas e indutores, inclusive provenientes debasidiomicetos, também tem-se verificado incremento na atividade dessa enzima. KUHN (2007) observou, em feijoeiros tratados com B. cereus, o aumento não significativo da atividade específica de $\beta-1,3$ glucanases, enquanto que o indutor abiótico ASMaumentou significativamente a atividade dessa enzima. GUARDA; DiPIERO (2007) observaram aumento da atividade de glucanases em plantas de feijão tratadas com quitosana e inoculadas com C. lindemuthianum. IURKIV (2009) verificou que frações proteicas, obtidas por cromatografia de filtração em gel a partir de extrato debasidiocarpode P.sanguineus, induziram a atividade específica de $\beta-1,3$ glucanases em cotilédones de soja, superior em $260 \%$ à testemunhaágua. FIORI-SuZUKI et al. (2008) verificaram aumento da atividade de $\beta-1,3$ glucanases em maracujazeiros inoculados com Xanthomonas campestris pv. passiflorae etratados com extratos debasidiocarpos de Lentinula edodes e Agaricus blazei nas concentrações 20 e $40 \%$. 

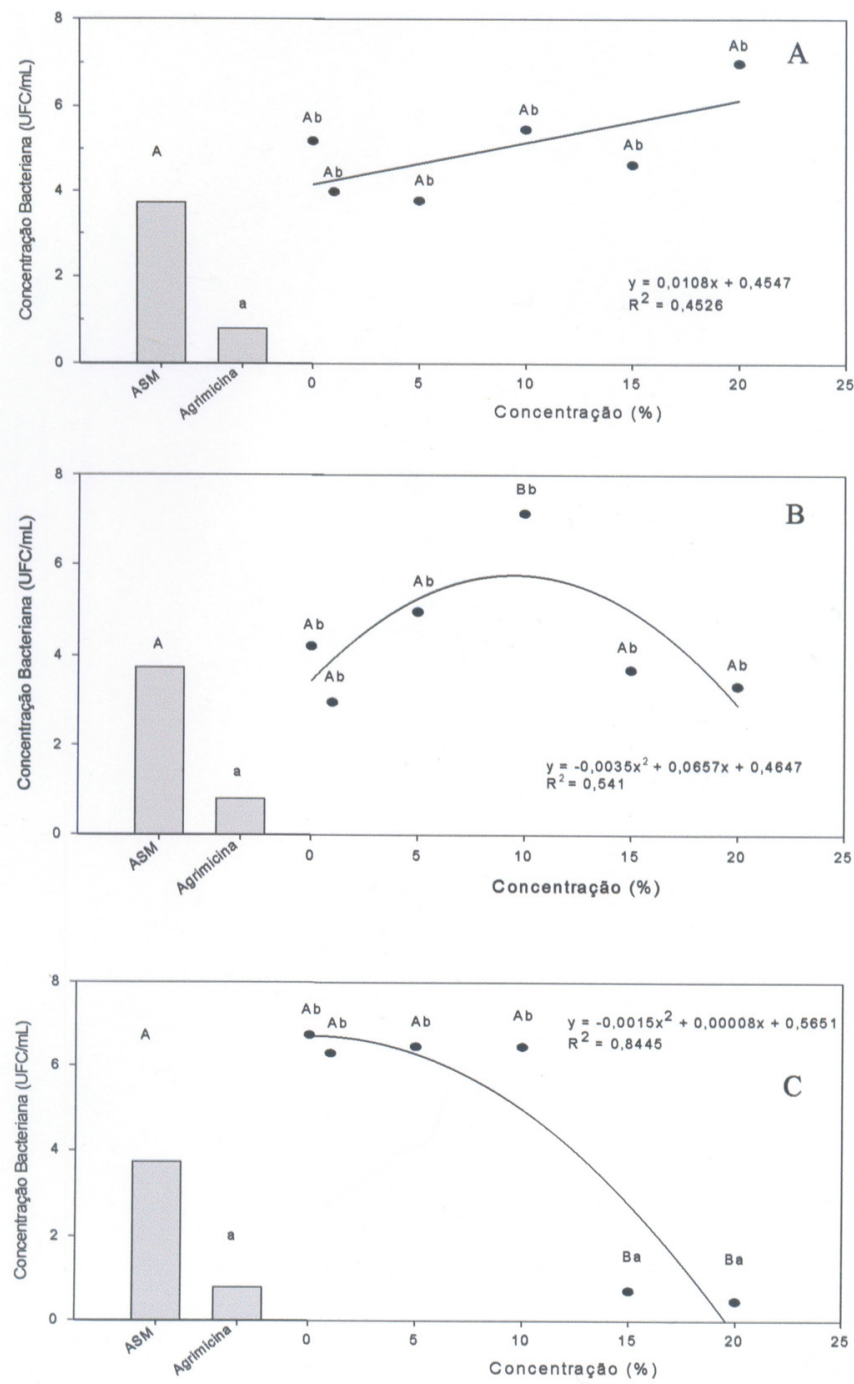

Fig. 1 - Efeito de diferentes concentrações de extrato aquoso de micélio (A), filtrado de cultura (B) e basidiocarpo (C) de Pycnoporus sanguineus sobre o crescimento de Xanthomonas axonopodis pv. phaseoli e sua comparação com o efeito de antibiótico (22,5 $\mathrm{mg} \mathrm{L}^{-1}$ de oxitetraciclina $+225 \mathrm{mg} \mathrm{L}^{-1}$ de estreptomicina) e acibenzolar-S-metil (ASM) (125 mg i.a. $\left.\mathrm{L}^{-1}\right)$, no crescimento bacteriano. Valores seguidos de mesma letra (maiúscula para comparação com ASM e minúscula para comparação com antibiótico) não diferem estatisticamente pelo teste de Tukey a 5\%.
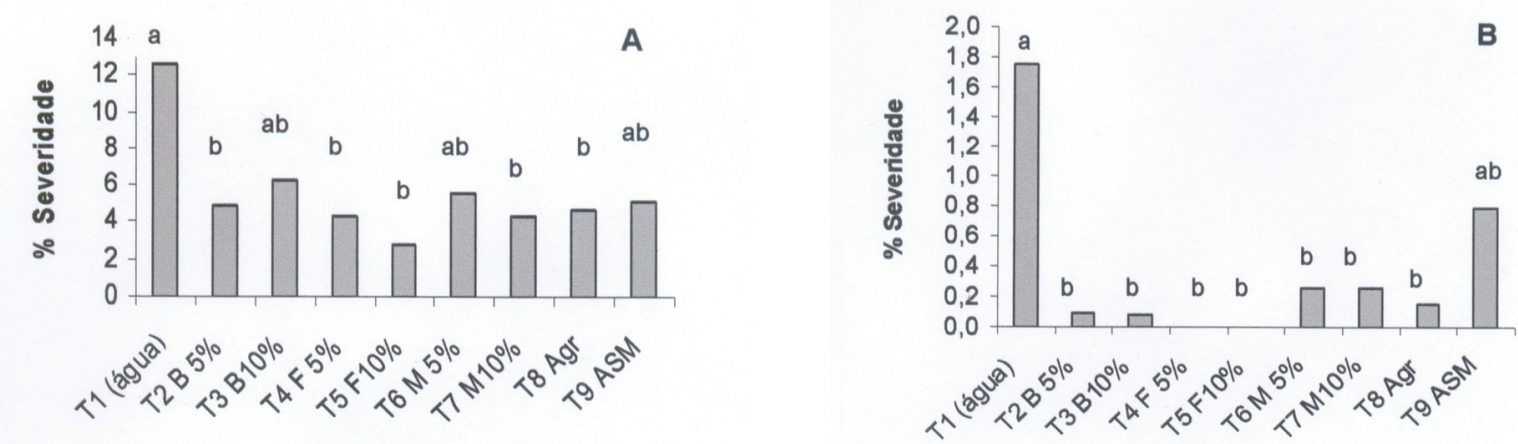

Fig. 2 - Severidade para crestamento bacteriano comum causado por X. axonopodis pv. phaseoli em feijoeiro em função dos tratamentos com extratos aquosos de basidiocarpo (T2B e T3B), de filtrado de cultura (T4F e T5F) e de micélio (T6M e T7M) de P. sanguineus em concentrações de 5 e $10 \%$, na primeira folha tratada e inoculada (A) e na segunda folha apenas inoculada (B), em condições de casa de vegetação. Agr: antibiótico $\left(22,5 \mathrm{mg} \mathrm{L}^{-1}\right.$ de oxitetraciclina $+225 \mathrm{mg} \mathrm{L}^{-1} \mathrm{de}$ estreptomicina); ASM: acibenzolar-S-metil (125 mg i.a. $\left.\mathrm{L}^{-1}\right)$. Médias seguidas de mesma letra minúscula não diferem significativamente entre si pelo teste de Tukey a $5 \%$. 


\section{Basidiocarpo}
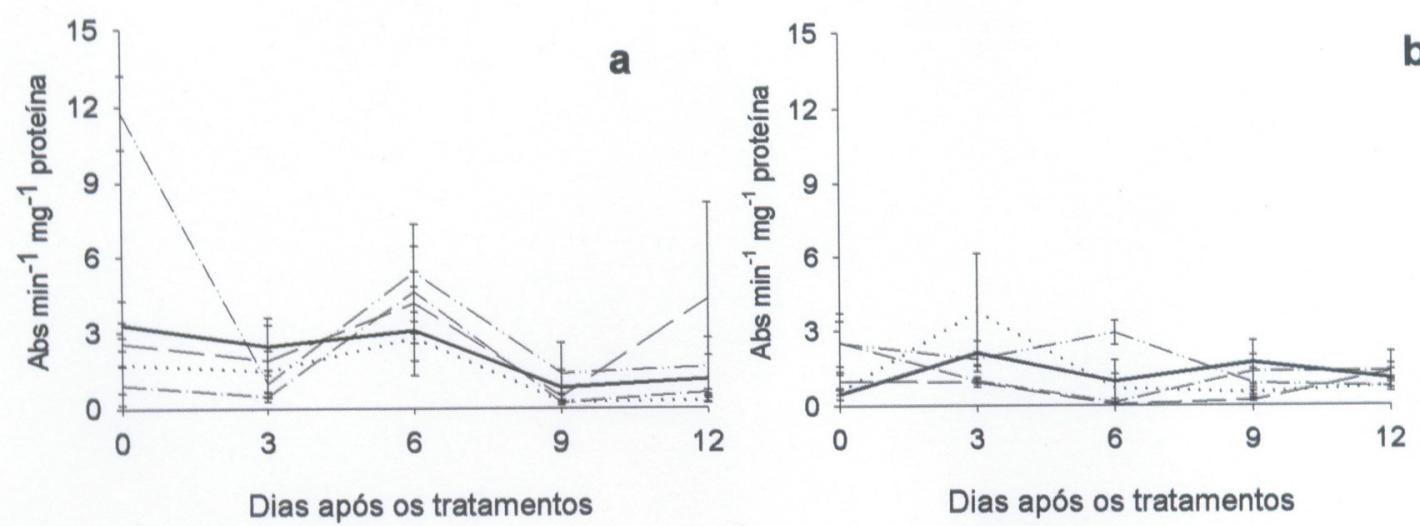

\section{Filtrado}
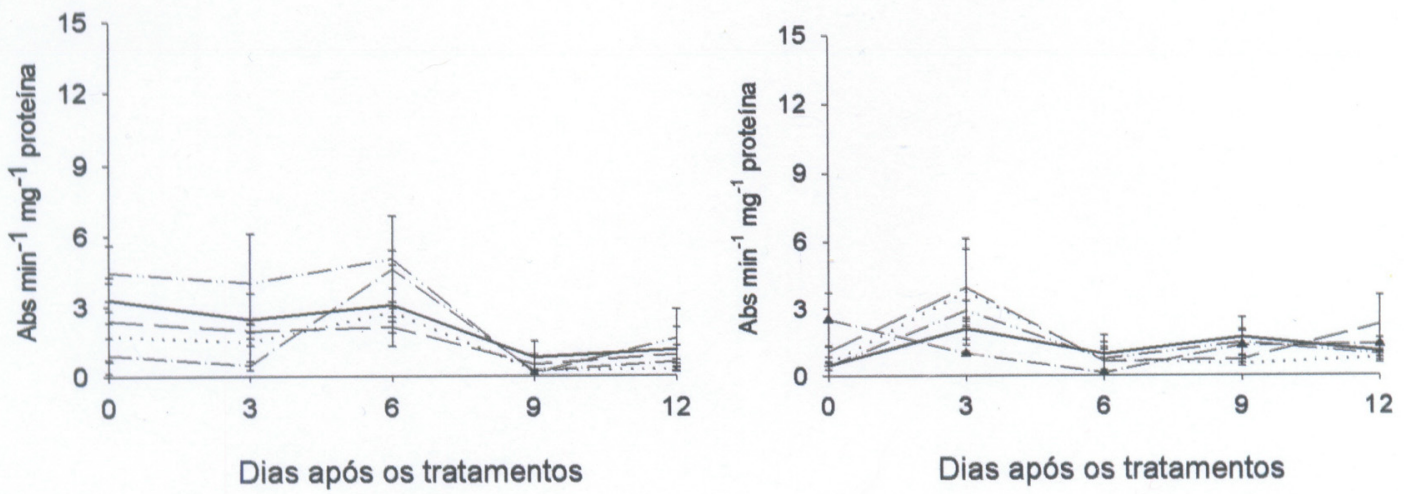

\section{Micélio}
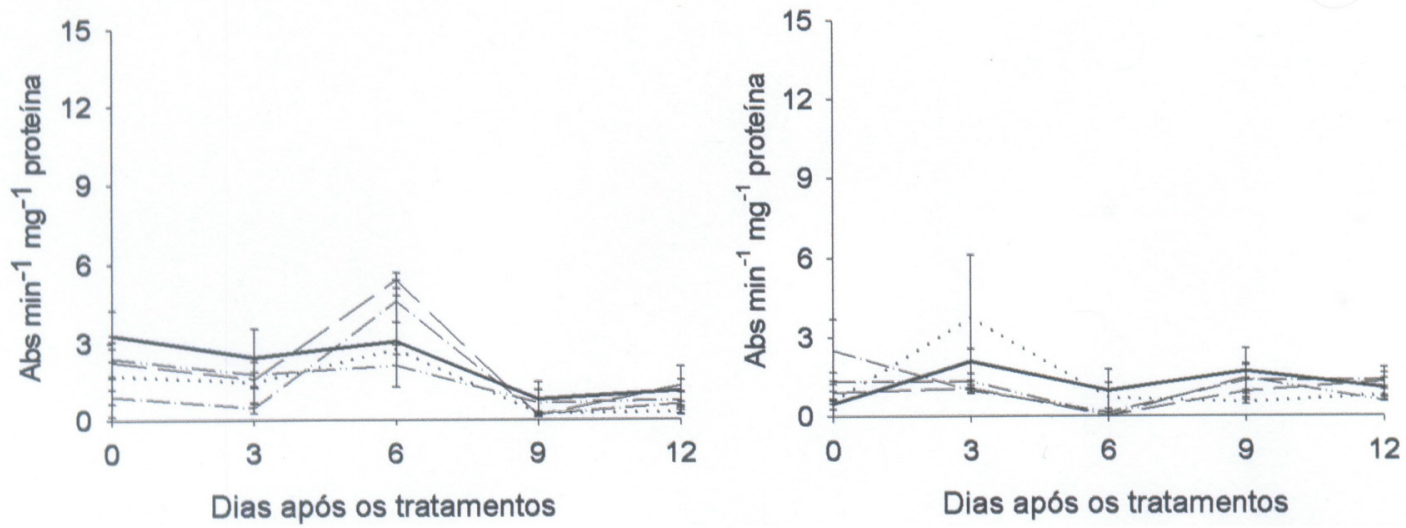

Fig. 3 - Atividade específica de peroxidase em plantas de feijoeiro inoculadas com Xanthomonas axonopodis pv. phaseoli três dias após os tratamentos com os controles água (-), antibiótico (Agrimicina: $22,5 \mathrm{mg} \mathrm{L}^{-1}$ de

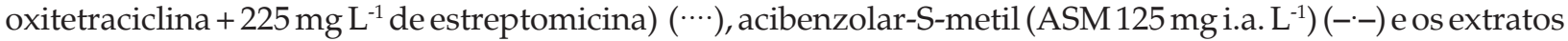
aquosos de Pycnoporus sanguineus obtidos do basidiocarpo, filtrado de cultura emicélio a $5 \%(-\cdot-)$, ebasidiocarpo, filtrado de cultura e micélio a $10 \%$ (--). (a) e (b) representam respectivamente a $1^{\text {a }}$ folha tratada e inoculada, e a $2^{a}$ folha apenas inoculada de planta tratada. Barras indicam a média $+/-$ o erro padrão. 


\section{Basidiocarpo}
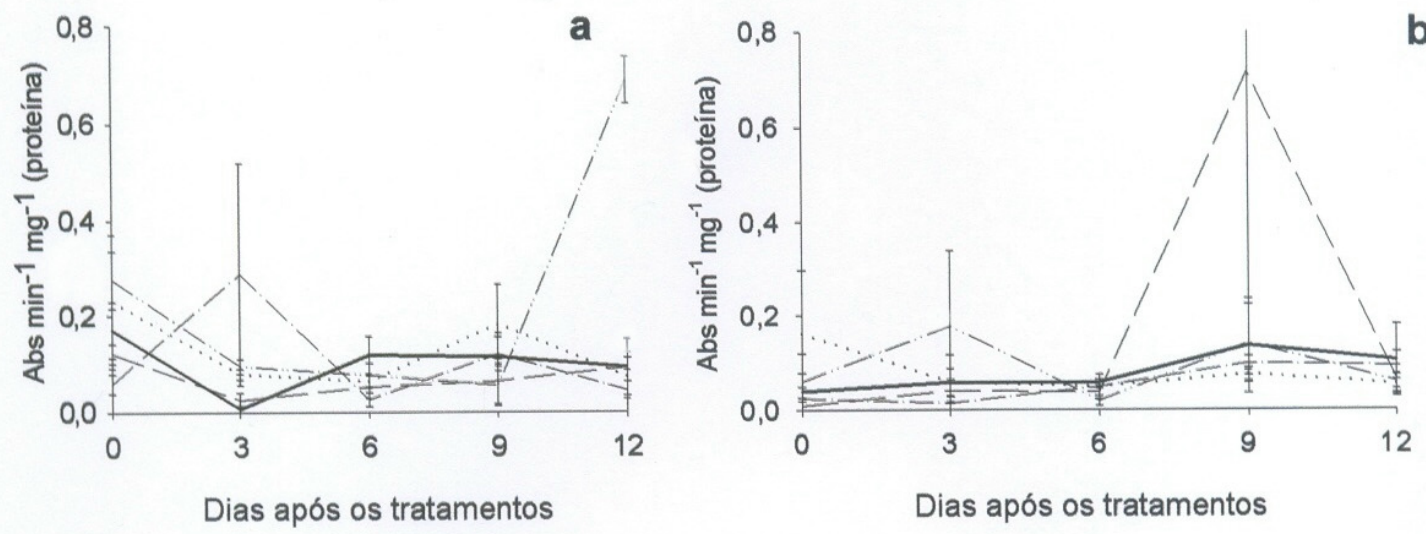

\section{Filtrado}
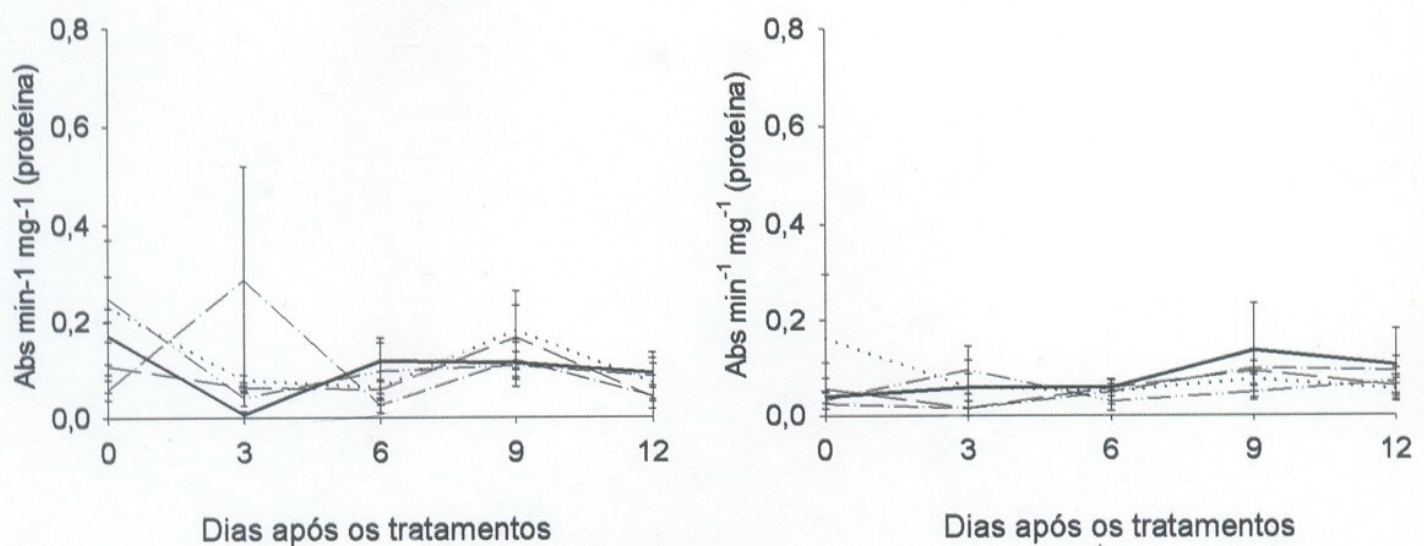

\section{Micélio}
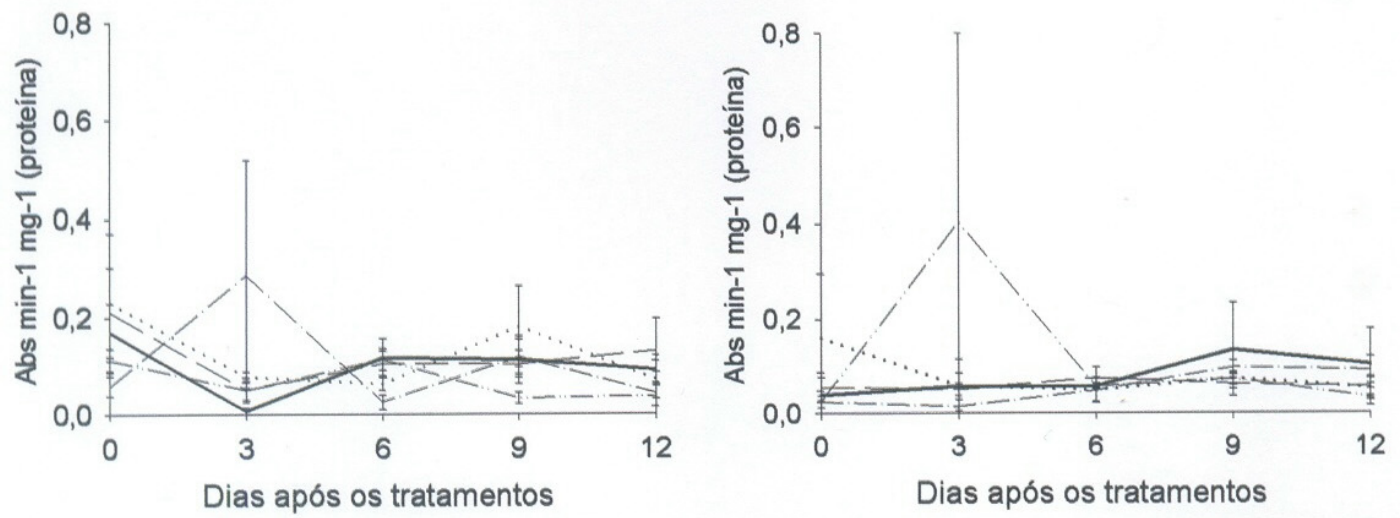

Fig. 4 - Atividade específica de polifenoloxidase em plantas de feijoeiro inoculadas com Xanthomonas axonopodis pv.

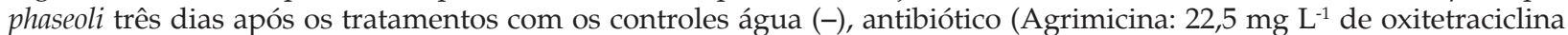
+ $225 \mathrm{mg} \mathrm{L}^{-1}$ de estreptomicina) ( $\cdots$ ), acibenzolar-S-metil (ASM $125 \mathrm{mg}$ i.a. $\mathrm{L}^{-1}$ ) (--) e os extratos aquosos de Pycnoporus sanguineus obtidos do basidiocarpo, filtrado de cultura e micélio a $5 \%\left(-{ }^{-*}\right)$, e basidiocarpo, filtrado de cultura e micélio a $10 \%$ (- -). (a) e (b) representam respectivamente a $1^{\text {a }}$ folha tratada e inoculada, e a $2^{\mathrm{a}}$ folha apenas inoculada de planta tratada. Barras indicam a média $+/-$ o erro padrão. 


\section{Basidiocarpo}
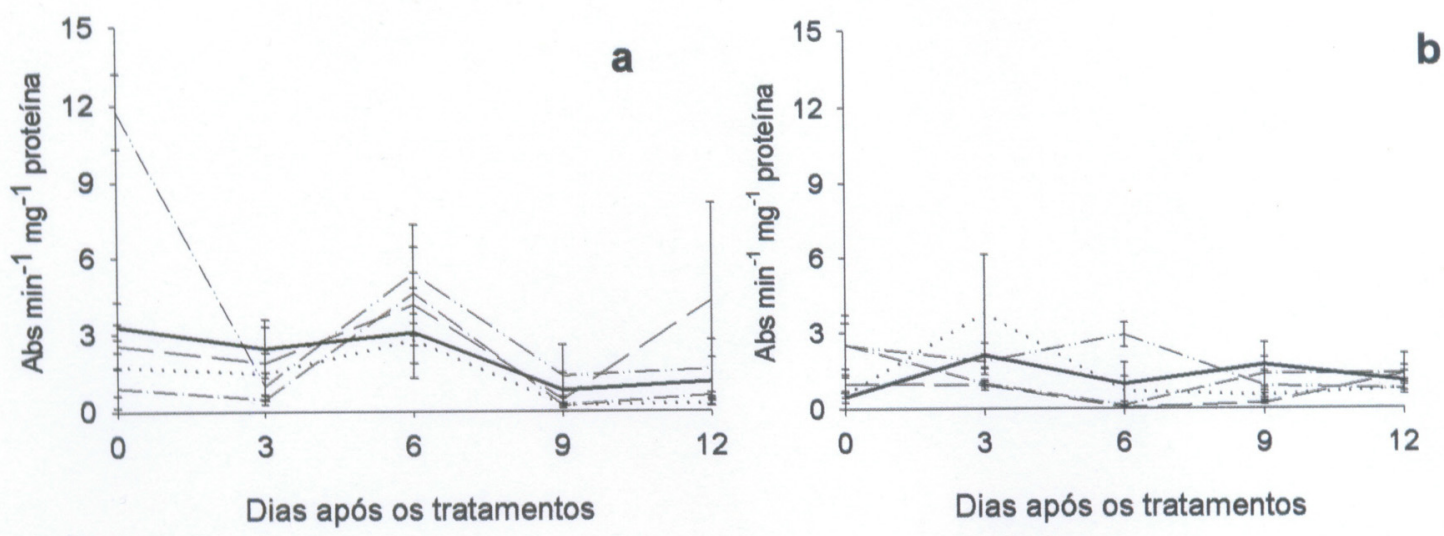

\section{Filtrado}
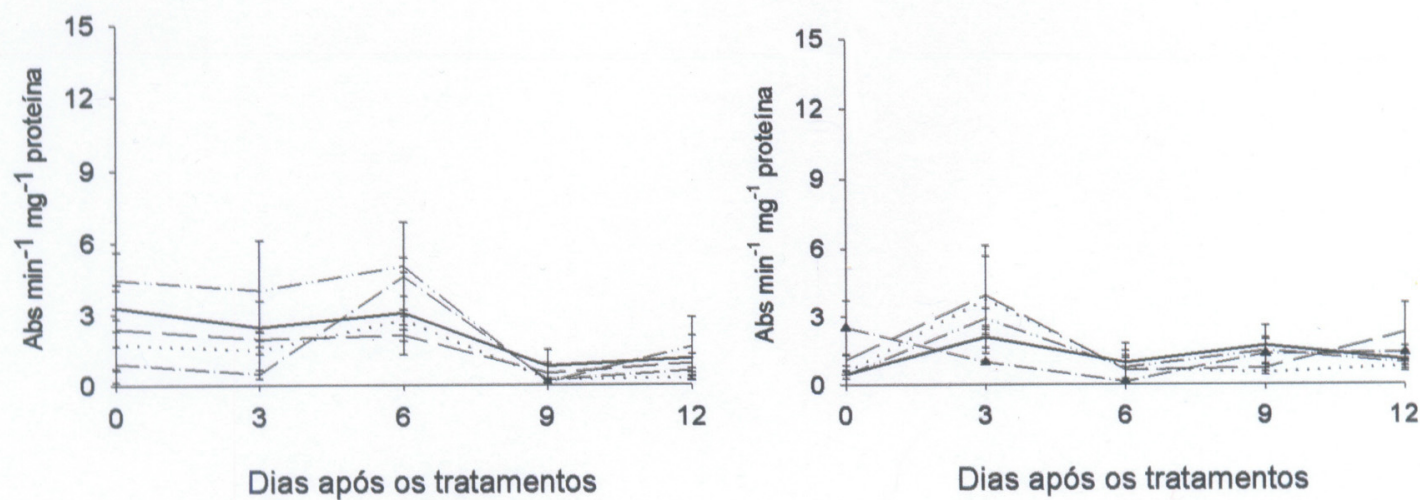

\section{Micélio}
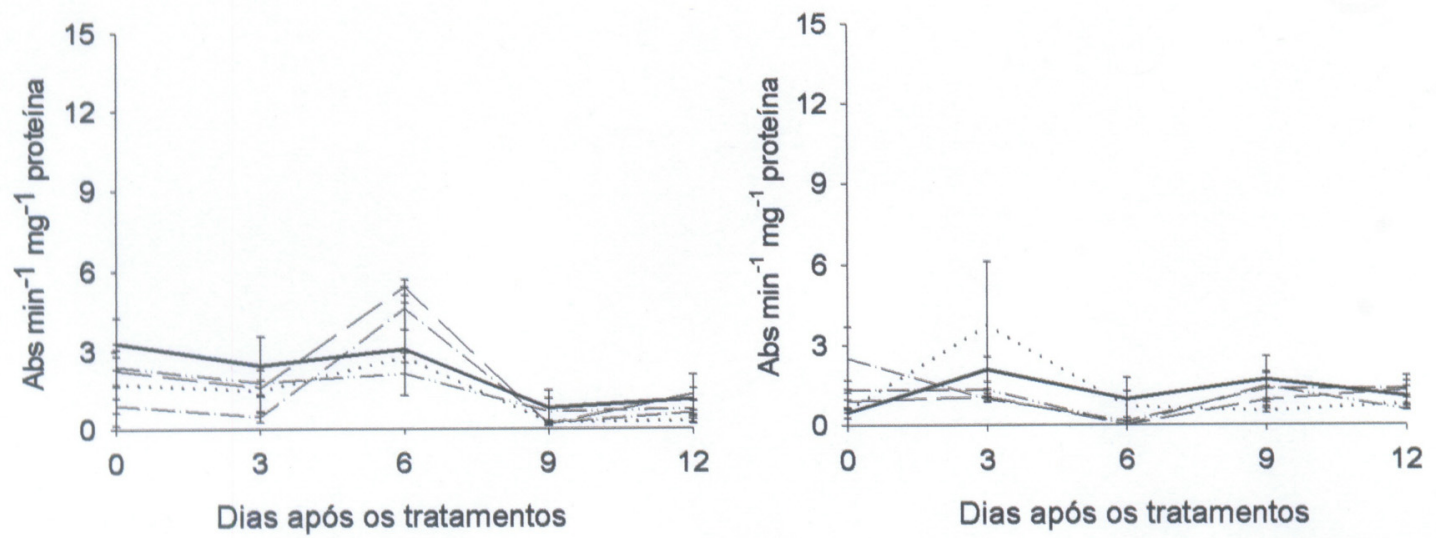

Fig. 5 - Atividade específica de fenilalanina amônia-liase em plantas de feijoeiro inoculadas com Xanthomonas axonopodis pv. phaseoli três dias após os tratamentos com os controles água (-), antibiótico (Agrimicina: 22,5 mg L $\mathrm{m}^{-1}$ de oxitetraciclina + $225 \mathrm{mg} \mathrm{L}^{-1}$ de estreptomicina) (‥) acibenzolar-S-metil (ASM $125 \mathrm{mg}$ i.a. $\mathrm{L}^{-1}$ ) (---) e os extratos aquosos de Pycnoporus sanguineus obtidos do basidiocarpo, filtrado de cultura e micélio a $5 \%(-\cdot-)$, e basidiocarpo, filtrado de cultura e micélio a $10 \%$ (- ). (a) e (b) representam respectivamente a $1^{\text {a }}$ folha tratada e inoculada, e a $2^{\mathrm{a}}$ folha apenas inoculada de planta tratada. Barras indicam a média $+/-$ o erro padrão. 


\section{Basidiocarpo}
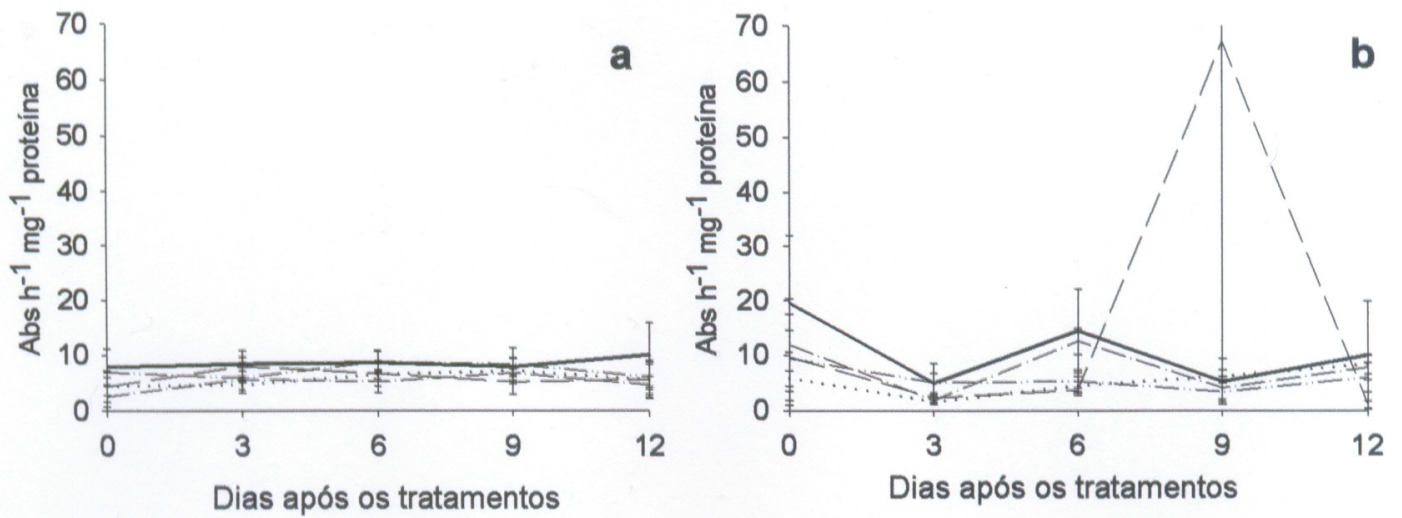

\section{Filtrado}
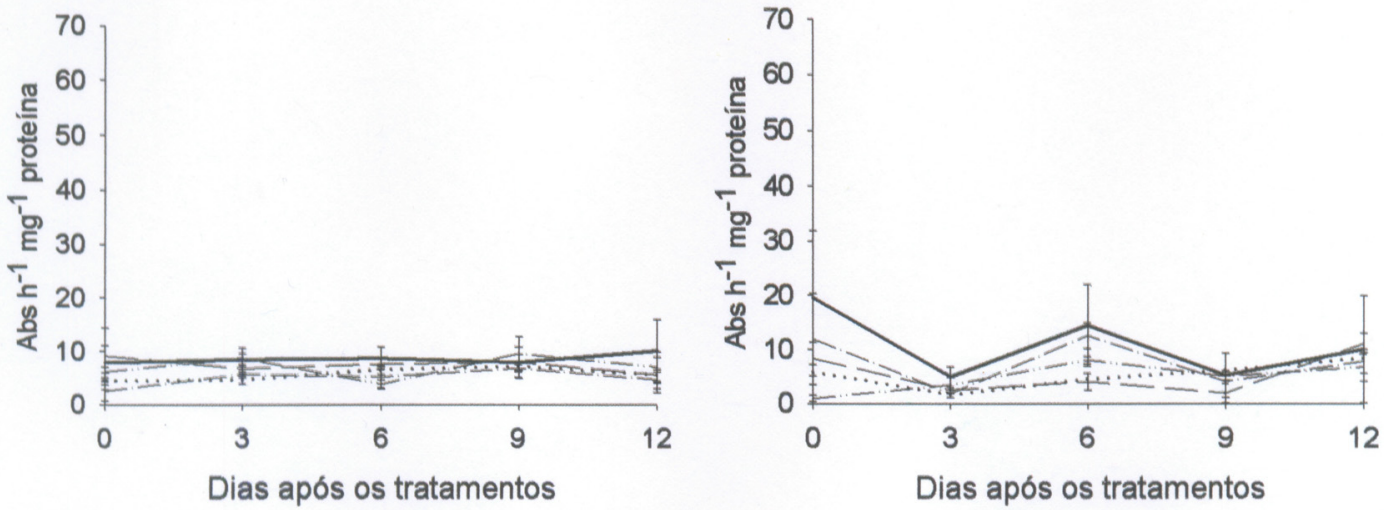

\section{Micélio}
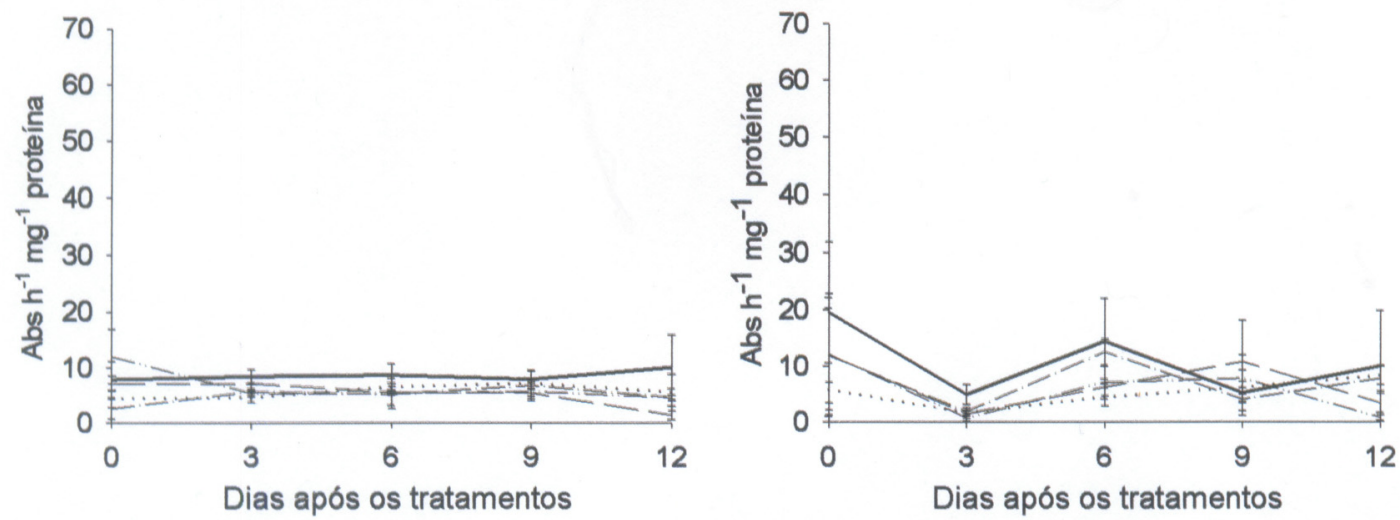

Fig. 6 - Atividade específica de $\beta-1,3$ glucanase em plantas de feijoeiro inoculadas com Xanthomonas axonopodis pv. phaseoli três dias após os tratamentos com os controles água (-), antibiótico (Agrimicina: 22,5 mg L-1 de oxitetraciclina + $225 \mathrm{mg}$ $\mathrm{L}^{-1}$ de estreptomicina) (‥) acibenzolar-S-metil (ASM $125 \mathrm{mg}$ i.a. $\left.\mathrm{L}^{-1}\right)(-\cdot-)$ e os extratos aquosos de Pycnoporus sanguineus obtidos do basidiocarpo, filtrado de cultura e micélio a $5 \%(-\cdot-)$, e basidiocarpo, filtrado de cultura e micélio a $10 \%$ $(--)$. (a) e (b) representam respectivamente a $1^{\text {a }}$ folha tratada e inoculada, e a $2^{\mathrm{a}}$ folha apenas inoculada de planta tratada. Barras indicam a média +/- o erro padrão. 
CAVALCANTI et al. (2006) verificaram que suspensão de quitosana, proveniente de micélio de Crinipellis perniciosa, conferiu capacidade parcial de proteção em plantas de tomateiro desafiadas por Xanthomonas campestris pv. vesicatoria, pela promoção do aumento na atividade de quitinase e $\beta-1,3$ glucanase.

Os resultados deste trabalho indicaram opotencial de extratos provenientes de $P$. sanguineus para o controle de X. axonopodis pv. phaseoli em feijoeiro, o que pode ocorrer tanto por atividade antimicrobiana direta quanto pela ativação das enzimas de defesa vegetal peroxidase e polifenoloxidase, com consequente redução da severidade da doença.

\section{AGRADECIMENTOS}

Os autores agradecem à Fundação Araucária e à FINEP pelo apoio financeiro na execução do projeto. JRS e KRFSE agradecem ao CNPq pela bolsa de produtividade em pesquisa.

\section{REFERENCIAS}

ASSI, L. Controle de Colletotrichum lindemuthianum (Sacc. Et Magn) Scrib, na cultura do feijão (Phaseolus vulgaris L.) pelo extrato do cogumelo Pycnoporus sanguineus (L. ex. Fr). 2005. 51p. Dissertação (Mestrado) - Universidade Estadual do Oeste do Paraná, Marechal Cândido Rondon, 2005.

BALDO, M. Aspectos histológicos e bioquímicos da indução de resistência em feijoeiro e atividade antifúngica por derivados de Pycnoporus sanguineus. 2008. 83p. Dissertação (Mestrado) - Universidade Estadual do Oeste do Paraná, Marechal Cândido Rondon, 2008.

BALDO, M.; IURKIV, L.; MEINERZ, C.C.; FRANZENER, G.; KUHN, O.J.; STANGARLIN, J.R. Inibição da germinação de esporos de Phakopsora euvitis e Uromyces appendiculatus pelo extrato de Pycnoporus sanguineus. Summa Phytopathologica, v.34, p.94, 2008. Suplemento.

BIANCHINI, A; MARINGONI, A.C.; CARNEIRO, S.M.T.P.G. Doenças do feijoeiro. In: KIMATI, H. AMORIM, L.; BERGAMIN FILHO, A.; CAMARGO, L.E.A.; REZENDE, J.A.M. (Ed.). Manual de fitopatologia Doenças das plantas cultivadas. São Paulo: Editora Ceres, 2005. p.333-349.

BRADFORD, M.M. A rapid and sensitive method for the quantification of microgram quantities of protein utilizing the principle of protein-dye binding. Analytical Biochemistry, v.72, p.248-254, 1976.

CAVALCANTI, F.R.; RESENDE, M.L.V.; PEREIRA R.B.; COSTA, J.C.B.; CARVALHO, C.P.S. Atividades de quitinase e beta-1,3-glucanase após elicitação das defesas do tomateiro contra a mancha-bacteriana. Pesquisa Agropecuária Brasileira, v.41, n.12, p.1721-1730, 2006.

DI PIERO, M.R.; PASCHOLATI, S.F. Indução de resistência em plantas de pepino contra Colletotrichum lagenarium pela aplicação de extratos de basidiocarpos de Lentinula edodes e de Agaricus blazei. Summa Phytopathologica, v.30, p.243-250, 2004.

DI PIERO, R.M.; GARCIA JUNIOR, D.; TONUCCI, N.M. Indutores bióticos. In: CAVALCANTI, L.S.; DI PIERO, R.M.; CIA, P.; PASCHOLATI, S.F.; RESENDE, M.L.V.; ROMEIRO, R.S. (Ed.). Indução de resistência em plantas a patógenos e insetos. Piracicaba: FEALQ, 2005. p.29-50.

DUANGMAL, K.; APENTEN, R.K.O. A comparative study of polyphenoloxidases from taro (Colocasia esculenta) and potato (Solanun tuberosum var. Romano). Food Chemistry, v.64, p.351-359, 1999.

FIORI-SUZUKI, C.C.L.; SCHWAN-ESTRADA, K.R.F.; BONALDO, S.M.; ITAKO, A.T.; TOLENTINO JUNIOR, J.B. Ativação da enzima glucanase em folhas de plantas de maracujazeiro tratadas com extratos dos cogumelos Agaricus blazei e Lentinula edodes. Summa Phytopathologica, v.34, p.104, 2008. Suplemento.

GUARDA, M.V.; DI PIERO, R.M. Atividade de glucanases e peroxidases em plantas de feijão tratadas com quitosana. Fitopatologia Brasileira, v.32, p.184, 2007. Suplemento.

IURKIV, L. Purificação parcial de compostos biologicamente ativos a partir de Pycnoporus sanguineus no controle de ferrugem asiática em soja. 2009. 117p. Dissertação (Mestrado) - Universidade Estadual do Oeste do Paraná, Marechal Cândido Rondon, 2009.

KUHN, O.J. Indução de resistência em feijoeiro (Phaseolus vulgaris) por acibenzolar-S-metil e Bacillus cereus: aspectos fisiológicos, bioquímicos e parâmetros de produção. 2007. 140p. Tese (Doutorado) - Escola Superior de Agricultura "Luis de Queiroz", Unversidade de São Paulo, Piracicaba, 2007.

LUSSO, M.F.G.; PASCHOLATI, S.F. Activity and isoenzymatic pattern of soluble peroxidases in maize tissues after mechanical injury or fungal inoculation. Summa Phytopathologica, v.25, p.244-249, 1999.

MARIANO, R.L.R.; SILVEIRA, E.B. Isolamento de bactérias fitopatogênicas. In: MARIANO, R.L.R. (Coord.). Manual de práticas em fitobacteriologia. Recife: Universidade Federal Rural de Pernambuco, 2000. p.27-35.

MEINERZ, C.C.; BALDO, M.; FRANZENER, G.; YURKIV, L.; BRAGA, C.L.; KUHN, O.J.; STANGARLIN, J.R. Potencial indutor de resistência em soja do extrato aquoso de P. sanguineus. Fitopatologia Brasileira, v.32, p.304, 2007. Suplemento. 
PEITER-BENINCA, C.P.; FRANZENER, G.; ASSI, L.; IURKIV, L.; ECKSTEIN, B.; COSTA, V.C.; NOGUEIRA, M.A.; STANGARLIN, J.R.; SCHWAN-ESTRADA, K.R.F. Indução de fitoalexinas e atividade de peroxidases em sorgo e soja tratados com extratos de basidiocarpos de Pycnoporus sanguineus. Arquivos do Instituto Biológico, São Paulo, v.75, n.3, p.285-292, 2008. Disponível: <http://www.biologico.sp.gov.br/docs/arq/v75_3/ beninca.pdf $>$.

RAVA, C.A.; SARTORATO, A. Crestamento bacteriano comum. In: SARTORATO, A.; RAVA, C. A. (Ed.). Principais doenças do feijoeiro comum e seu controle. Brasília: Embrapa, 1994. p.217-242.

SARTORATO, A.; RAVA, C.A.; RIOS, G.P. Doenças fúngicas e bacterianas da parte aérea. In: ARAÚJO, S.A.; RAVA, C.A.; STONE, L.F.; ZIMMERMANN, M.J.O. (Ed.). A cultura do feijoeiro comum no Brasil. Piracicaba: Associação Brasileira para a Pesquisa da Potassa e do Fosfato, 1996. p.669-722.

SCHWAN-ESTRADA, K.R.F.; STANGARLIN, J.R. Extratos e óleos essenciais de plantas medicinais na indução de resistência. In: CAVALCANTI, L.S.; DI PIERO, R.M.; CIA, P.; PASCHOLATI, S.F.; RESENDE, M.L.V.; ROMEIRO, R.S. (Ed.). Indução de Resistência em Plantas a Patógenos e Insetos. Piracicaba: FEALQ, 2005. p.125-138.

SMÂNIA, A.; DELLE MONADHE, F.; SMÂNIA, E.F.A.; GIL, M.L.; BENCHETRIT, L.C.; CRUZ, F.S. Antibacterial activity of a substance produced by the fungus Pycnoporus sanguineus (Fr.) Murr. Journal of Ethnopharmacology, v.45, p.177-181, 1995.

STANGARLIN, J.R.; PASCHOLATI, S.F. Atividades de ribulose-1,5-bifosfato carboxilase-oxigenase (rubisco), clorofilase, $\beta-1,3$ glucanase e quitinase e conteúdo de clorofila em cultivares de feijoeiro (Phaseolus vulgaris) infectados com Uromyces appendiculatus. Summa Phytopathologica, v.26, p.34-42, 2000.
STANGARLIN, J.R.; SCHWAN-ESTRADA, K.R.F.; CRUZ, M.E.S.; NOZAKI, M.H. Plantas medicinais e controle alternativo de fitopatógenos. Biotecnologia Ciência \& Desenvolvimento, n.11, p.16-21, 1999.

STANGARLIN, J.R.; PASCHOLATI, S.F.; FRANZENER, G. Phenols, $\beta-1-3$ glucanase, chitinase and phenylananine ammonia-lyase activities in infection sites of Exserohilum turicum in maize genotypes. Summa Phytopathologica, v.31, n.3, p. 261-267, 2005.

STANGARLIN, J.R.; KUHN, O.J.; SCHWAN-ESTRADA, K.R.F. Controle de doenças de plantas por extratos de origem vegetal. Revisão Anual de Patologia de Plantas, v.16, p.265-304, 2008.

VALE, F.X.R.; COSTA, H.; ZAMBOLIM, L. Feijão comum: doenças da parte aérea causada por fungos. In: VALE, F.X.R.; ZAMBOLIM, L. (Ed.). Controle de doenças de plantas: grandes culturas. Brasília: Ministério da Agricultura e do Abastecimento, 1997. v.1, p.341-350.

VALE, F.X.R.; FERNANDES FILHO, E.I.; LIBERATO, J.R. A software for plant disease severity assessment. In: INTERNATIONAL CONGRESS OF PLANT PATHOLOGY, 8., 2003, Christchurch, New Zealand. Anais. Christchurch, 2003. p.105.

VIECELLI, C.A. Controle da mancha angular e análise bioquímica de resistência em feijoeiro tratado com extratos de Pycnoporus sanguineus. 2008. 60p. Dissertação (Mestrado) - Universidade Estadual do Oeste do Paraná, Marechal Cândido Rondon, 2008.

VIECELLI, C.A.; KUHN, O.J.; STANGARLIN, J.R. Efeito in vitro de extratos de Pycnoporus sanguineus sobre Pseudocercospora griseola. Summa Phytopathologica, v.34, p.52, 2008. Suplemento.

Recebido em 11/5/09

Aceito em 13/10/09 